\title{
METHOTREXATE ACTION IN RHEUMATOID ARTHRITIS: STIMULATION OF CYTOKINE INHIBITOR AND INHIBITION OF CHEMOKINE PRODUCTION BY PERIPHERAL BLOOD MONONUCLEAR CELLS
}

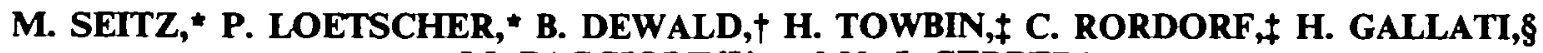 \\ M. BAGGIOLINI $\dagger$ and N. J. GERBER* \\ -Division of Rheumatology, University Hospital, Inselspital, Bern, †Theodor-Kocher-Institute, University of Bern, \\ $\ddagger$ Ciba-Geigy and \$F. Hoffmann-La Roche, Basel, Switzerland
}

\begin{abstract}
SUMMARY
This open label study examines whether methotrexate (MTX) treatment modulates ex vivo synthesis of interleukin-1 receptor antagonist (IL-1 ra), soluble tumour necrosis factor receptors (sTNFR p55 and p75), interleukin-1 $\beta$ (IL-1 $\beta$ ), tumour necrosis factor $\alpha$ (TNF- $\alpha$ ), interleukin-8 (IL-8) and monocyte chemoattractant protein-1 (MCP-1) by peripheral blood mononuclear cells (PBMC) and whether changes reflect clinical response. Significant stimulation of IL-1 ra and sTNFR p75 as well as inhibition of IL-8 production of PBMC were associated with clinical improvement observed in patients treated with MTX. When defining the characteristics of patients at study entry retrospectively in responders and non-responders, a significantly lower ratio of IL-1 ra:IL-1 $\beta$ production before and its increase upon treatment was associated with clinical response in 13 patients compared to five patients not responding to MTX. In addition, clinical improvement was associated with decreased synthesis of IL-1 $\beta$, TNF- $\alpha$ and IL-8 induced by bacterial lipopolysaccharide, IL- $1 \alpha$ and IL- $1 \beta$ in PBMC in vitro. These findings suggest that MTX therapy reverses the inflammatory type of rheumatoid arthritis (RA) blood mononuclear cells by stimulating cytokine inhibitor production while inhibiting inflammatory cytokine release at the same time. This may explain the powerful anti-inflammatory properties of low-dose MTX as observed in most RA patients. Pretreatment determination of the IL-1ra:IL-1 $\beta$ ratio in PBMC may be predictive with regard to a favourable therapeutic response and therefore may be useful for the selection of RA patients to be treated with MTX.
\end{abstract}

KEY wORDS: Methotrexate, Cytokines, Cytokine inhibitors, Rheumatoid arthritis.

WEERLY low-dose treatment with methotrexate (MTX) is highly effective in rheumatoid arthritis (RA) [1-4], and has supplanted classic second-line drugs such as injectable gold because of its superior efficacy/toxicity trade-offs [5]. Its mode of action in RA, however, is poorly understood. Most studies of immune function in RA patients treated with MTX show only marginal effects ón humoral and cellular immune responses [6]. The rapid clinical remission as observed in the majority of RA patients upon MTX treatment and the fast flare of disease after drug discontinuation [7] suggest that the mechanism of action of MTX in RA might be more anti-inflammatory than immunosuppressive. As shown in recent studies MTX appears to interfere directly with the action of pro-inflammatory cytokines such as interleukin-1 (IL-1) [8-10]. MTX also inhibits IL-1 production by macrophages in rat adjuvant arthritis $[11,12]$, interleukin-8 (IL-8) production by peripheral blood mononuclear cells (PBMC) [13], leukotriene $\mathrm{B}_{4}$ synthesis in neutrophils [14], and decreases selectively synovial collagenase gene expression [15]. Recent data suggest that MTX increases the release of adenosine by connective tissue cells, which might inhibit neutrophil adherence to endothelial cells and fibroblasts [16].

Submitted 8 December 1994; revised version accepted 11 April 1995.

Correspondence to: M. Seitz, Division of Rheumatology, University Hospital, Inselspital, CH-3010 Bern, Switzerland.
The effect of MTX on cytokine synthesis is particularly important in RA, since mediators like IL-1 and tumour necrosis factor $\alpha$ (TNF- $\alpha$ ) play a key role in the perpetuation of synovial inflammation [17], but there is no information whether this drug may also affect cytokine inhibitor production. Although physiological cytokine inhibitors such as interleukin-1 receptor antagonist (IL-1 ra) and soluble TNF- $\alpha$ receptors are released during the inflammatory synovial process [18-20], their action is obviously insufficient to prevent the pathophysiological events mediated by IL-1 and TNF- $\alpha$. We have studied the effects of low-dose MTX treatment in RA patients by ex vivo assessment of its effects on cytokine inhibitor and inflammatory cytokine production by PBMC and correlated the results with the clinical course of the disease.

\section{PATIENTS AND METHODS}

\section{Patients}

Eighteen patients with active RA were treated for up to 24 weeks with weekly intramuscular injections of $15 \mathrm{mg}$ MTX. Active RA was defined by fulfilment of at least three of the following four criteria: six or more joints tender or painful on motion, three or more swollen joints, erythrocyte sedimentation rate (ESR) $\geqslant 28 \mathrm{~mm} / \mathrm{h}$ and morning stiffness $\geqslant 45 \mathrm{~min}$ in duration. MTX and dosage of concomitant non-steroidal antiinflammatory drugs (NSAIDs) and steroids ( $\leqslant 7.5 \mathrm{mg}$ prednisone/day) were kept constant during the whole study. Clinical assessment was performed before, and 
6, 12 and 24 weeks after starting MTX therapy. Laboratory assessment before and during treatment included ESR, routine haematology, erythrocyte folinic acid, serum transaminases, alkaline phosphatase and creatinine.

After 12 weeks of treatment the patients were divided retrospectively into two groups, 'responders' and 'nonresponders', according to a composite activity index which was previously described [21]. The original index was modified in that in our study 'responders' had to fulfil the criteria of $a \geqslant 50 \%$ improvement from baseline for morning stiffness, Westergreen ESR, tenderjoint and swollen-joint scores $(60$ and 58 joints, respectively, hips not assessed for swelling; graded $0-3$ ), and the patient's and physician's assessment of disease severity [on a five-point scale, ranging from 1 (symptom-free) to 5 (very severe)]. Patients with deterioration of disease upon treatment were defined as 'non-responders'.

\section{Cells}

Venous blood was drawn from RA patients 6-10 h after the last intramuscular injection of MTX and blood mononuclear cells were isolated immediately by Ficoll-Hypaque fractionation [22] afterwards. The cells were washed three times in PBS and resuspended in culture medium $\left(10^{6}\right.$ cells $\left./ \mathrm{ml}\right)$. Viability was tested by trypan blue exclusion (87-96\% viable cells). The number of monocytes was determined by differential counting after staining for non-specific esterase [23]. Monocyte counts in PBMC of patients ranged between 14 and $46 \%$ interindividually before treatment and no statistically significant intra- and intergroup as well as intraindividual differences were observed throughout the study. Based on this observation, there was no need for improving the cytokine values in cell culture supernatants with reference to the percentage of monocytes among PBMC. Cells $\left(2 \times 10^{3}\right)$ in $0.2 \mathrm{ml}$ RPMI 1640 supplemented with $100 \mathrm{IU} / \mathrm{ml}$ penicillin/streptomycin (Gibco, Basel, Switzerland), and $1 \%$ pasteurized plasma protein solution (5\% PPL SRK, Swiss Red Cross) were incubated with or without different stimuli in flat-bottom microtitre plates (Nunc, Denmark) in a humidified atmosphere of $5 \% \mathrm{CO}_{2}$ at $37^{\circ} \mathrm{C}$ for $48 \mathrm{~h}$. Cell culture supernatants were collected and stored at $-70^{\circ} \mathrm{C}$ until use.

\section{Cytokine assays}

Interleukin-1 was determined by IL-1 $\beta$ specific and two-site directed enzyme-linked immunoassay (ELISA) with an exclusion limit of $8 \mathrm{pg} / \mathrm{ml}$ and an inter-assay variability of $5-27 \%$ [24]. Levels of IL-1 ra were measured by a specific ELISA using a newly developed monoclonal antibody and a rabbit antiserum with a lower detection limit of $20 \mathrm{pg} / \mathrm{ml}$ [25]. TNF- $\alpha$ was assessed by a specific ELISA (lower detection limit $20 \mathrm{pg} / \mathrm{ml}$ ) method as previously described [26] and soluble TNF- $\alpha$ receptors (p55 and p75) were measured by an enzyme-linked binding assay with a sensitivity of $100 \mathrm{pg} / \mathrm{ml}[27]$. The TNF- $\alpha$ assay did not interfere with the addition of high concentrations of recombinant soluble tumour necrosis factor receptors (sTNFR) (p55 and $\mathrm{p} 75$ ) to medium containing known amounts of TNF- $\alpha$. The determination of sTNFR (p55 and p75) was not influenced by up to $10 \mathrm{ng} / \mathrm{ml}$ of TNF- $\alpha$ in the same cell culture medium. For the determination of IL-8 a solid phase double-ligand ELISA method with a lower detection limit of $50 \mathrm{pg} / \mathrm{ml}$ was used [28]. MCP-1 was assessed by a highly specific ELISA which detects MCP-1 levels above $40 \mathrm{pg} / \mathrm{ml}$ [29]. All ELISAs used had a $100 \%$ recovery after addition of definite amounts of recombinant cytokines to culture media. All cytokine values were determined twice from duplicates, and the mean of four separate determinations from each patient sample at a given time is presented.

\section{Reagents}

Interleukin- $1 \alpha$ and interleukin- $\beta$ (kind gift of Dr J. Vosbeck, Ciba-Geigy, Basel, Switzerland) were used at $10 \mathrm{ng} / \mathrm{ml}$ and LPS from Escherichia coli (Gibco Cult, Basel, Switzerland) at $100 \mathrm{ng} / \mathrm{ml}$. These concentrations were shown to have maximum effects on either cytokine and cytokine inhibitor production of PBMC in prior dose-response experiments. Reagents for the TNF- $\alpha$ ELISA were kindly provided by F. Hoffmann-La Roche (Basel, Switzerland). All cytokine preparations and other reagents were free of bacterial lipopolysaccharide (LPS) as assessed by a negative limulus assay.

\section{Statistics}

Intragroup comparisons were performed using the Student's $t$-test (responders) and the Wilcoxon rankedsum test (non-responders). Intergroup differences were assessed by the Wilcoxon ranked-sum test. Results were considered statistically significant at $P<0.05$.

\section{RESULTS}

\section{Characteristics of patients at study entry}

Based on a composite activity index for evaluation of the efficacy of second-line drugs [21], 13 patients $(72.2 \%)$ fulfilled the criteria of 'responders' whereas only five patients $(27.8 \%)$ had to be classified as

TABLE I

Characteristics of patients at study entry

\begin{tabular}{lcc}
\hline & $\begin{array}{c}\text { Responders } \\
(n=13)\end{array}$ & $\begin{array}{c}\text { Non- } \\
\text { responders } \\
(n=5)\end{array}$ \\
\hline Age (yr) & $57.4 \pm 17.2^{*}$ & $57.8 \pm 16$ \\
Males/females & $1 / 12$ & $1 / 4$ \\
Duration of RA (yr) & $3.8 \pm 4.2$ & $6.7 \pm 9.3$ \\
ESR (mm/h) & $64 \pm 34$ & $69 \pm 34$ \\
Positive rheumatoid factor & $12(92) \dagger$ & $4(80)$ \\
Swollen-joint count (0-58) & $17.8 \pm 6.4$ & $15.6 \pm 4.6$ \\
Tender-joint count (0-60) & $23.7 \pm 8.9$ & $20.6 \pm 5.5$ \\
Morning stiffness (min) & $127 \pm 59$ & $144 \pm 100$ \\
Erosive disease (\% of patients) & 77 & 60 \\
Concurrent therapy & $13(100)$ & $5(100)$ \\
$\quad$ NSAIDs (number of patients) & 13 & $1(20)$ \\
NSAIDs + prednisone & & \\
$\quad$ (<10 mg/day) & $1(8)$ &
\end{tabular}

*Values are given as the mean \pm s.D.

†Percentage in parentheses. 

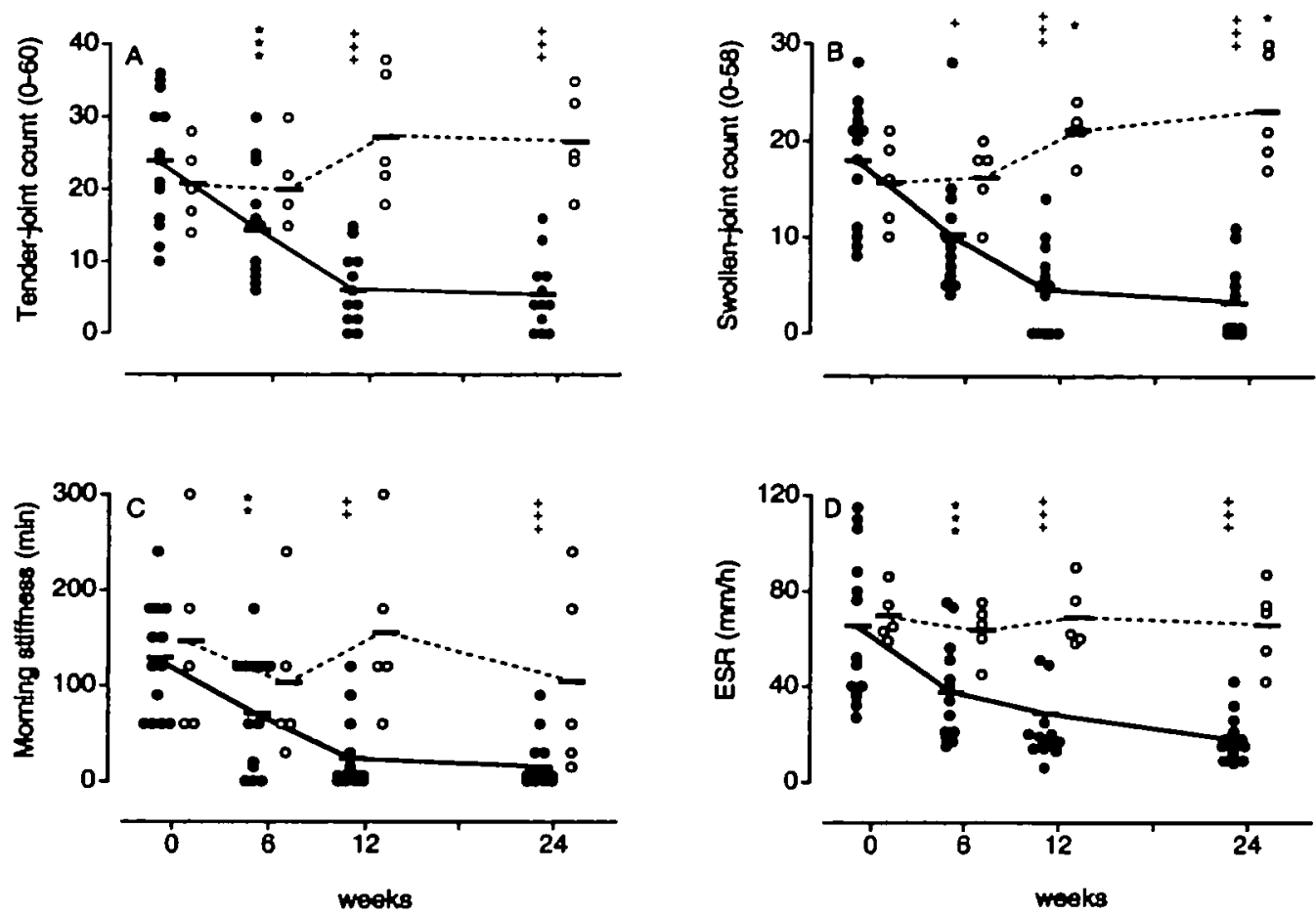

FIG. 1.-Parameters of rheumatoid arthritis disease activity before and during 24 weeks of methotrexate (MTX) treatment in responders $(O ; n=13)$ and non-responders $(O ; n=5)$. The tender-joint counts (A), the swollen-joint count (B), duration of morning stiffness in minutes (C) and the erythrocyte sedimentation rate $(\mathrm{mm} / \mathrm{h})(\mathrm{D})$ were determined before and, 6, 12 and 24 weeks after starting MTX treatment. Values of individual patients and the corresponding means of responders and non-responders are shown. ${ }^{*} P<0.05,{ }^{* *} P<0.025,{ }^{* *} P<0.01$, ${ }^{+} P<0.005,{ }^{++} P<0.0005,{ }^{++} P<0.0001$ (refers to intragroup comparisons).

'non-responders' after a 12-week treatment with lowdose MTX. Thus, the classification of 'responders' and 'non-responders' was performed retrospectively. Table I shows that the clinical entry variables did not differ significantly between the two outcome groups.

\section{Clinical parameters of disease activity before and during MTX treatment}

Figure 1 shows the changes of clinical parameters of disease activity like tender- and swollen-joint score, duration of morning stiffness and the ESR before and during 24 weeks of MTX treatment. Responding patients exhibited a significant reduction of the number of tender and swollen joints, duration of morning stiffness and the ESR $(P<0.025-0.005)$ already after
6 weeks of treatment. In this group of patients further amelioration of disease activity was observed after 12 and 24 weeks of MTX therapy $(P<0.0005-0.0001)$. In contrast, non-responding patients exhibited at least increasing swollen-joint counts after 12 and 24 weeks of treatment compared to baseline values $(P<0.05)$.

\section{Pretreatment cytokine and cytokine inhibitor production of $P B M C$}

As shown in Table II constitutive IL- $1 \beta$ production by PBMC from 'responders' before treatment was significantly higher $(P<0.025)$ and IL-I ra release slightly lower $(P<0.05)$ compared with 'nonresponders'. Consequently, RA patients responding to treatment exhibited a lower IL-1 ra:IL- $1 \beta$ ratio than

TABLE II

Pretreatment concentrations of IL-1 $\beta$, IL-1 ra, TNFa, sTNFR (p55 and p75), IL-8, MCP-1 and the ratio of IL-Ira: IL-1 $\beta$ levels in culture supernatants of unstimulated PBMC of responding, non-responding RA patients and healthy control individuals

\begin{tabular}{|c|c|c|c|c|c|c|c|c|}
\hline Group (n) & $\begin{array}{c}\text { IL-1 } \beta \\
\text { (ng/ml) }\end{array}$ & $\begin{array}{l}\text { IL-I ra } \\
(\mathrm{ng} / \mathrm{ml})\end{array}$ & IL-|ra:IL-1 $\beta$ & $\begin{array}{l}\text { TNF- } \alpha \\
(\mathrm{ng} / \mathrm{ml})\end{array}$ & $\begin{array}{c}\mathrm{p} 55 \\
(\mathrm{ng} / \mathrm{ml})\end{array}$ & $\begin{array}{c}\mathrm{p} 75 \\
(\mathbf{n g} / \mathrm{ml})\end{array}$ & $\begin{array}{c}\mathrm{IL-8} \\
(\mathrm{ng} / \mathrm{ml})\end{array}$ & $\begin{array}{l}\mathrm{MCP}-\mathrm{I} \\
(\mathrm{ng} / \mathrm{ml})\end{array}$ \\
\hline $\begin{array}{l}\text { Respanding (13) } \\
\text { Mean } \pm \text { S.D. } \\
\text { Range }\end{array}$ & $\begin{array}{l}0.16 \pm 0.18^{* \bullet} \\
0.01-0.51\end{array}$ & $\begin{array}{c}3.37 \pm 2.42^{*} \\
0.50-7.30\end{array}$ & $\begin{array}{l}52 \pm 43^{* * *} \\
2-117\end{array}$ & $<0.02$ & $\begin{array}{c}0.54 \pm 0.20 \\
0.22-0.95\end{array}$ & $\begin{array}{c}0.59 \pm 0.51 \\
0.18-1.99\end{array}$ & $\begin{array}{c}13.0 \pm 13.0 \\
0.6-43.6\end{array}$ & $\begin{array}{r}0.25 \pm 0.65 \\
<0.04-2.43\end{array}$ \\
\hline $\begin{array}{l}\text { Non-responding } \\
\text { Mean } \pm \text { S.D. } \\
\text { Range }\end{array}$ & $\begin{array}{l}\text { (5) } \\
0.03 \pm 0.02 \\
0.01-0.06\end{array}$ & $\begin{array}{c}6.48 \pm 3.42 \\
2.10-11.70\end{array}$ & $\begin{array}{r}466 \pm 455 \\
88-1170\end{array}$ & $\begin{array}{c}0.04 \pm 0.09 \\
<0.02-0.2\end{array}$ & $\begin{array}{c}0.46 \pm 0.20 \\
0.25-0.70\end{array}$ & $\begin{array}{c}0.42 \pm 0.15 \\
0.17-0.55\end{array}$ & $\begin{array}{c}9 \pm 8.2 \\
1.2-19.7\end{array}$ & $<0.04$ \\
\hline $\begin{array}{l}\text { Heallhy control } \\
\text { Mean } \pm \text { S.D. } \\
\text { Range }\end{array}$ & $\begin{array}{c}\text { individuals (6) } \\
0.009 \pm 0.01 \\
<0.008-0.02\end{array}$ & $\begin{array}{c}2.94 \pm 2.05 \\
0.86-5.88\end{array}$ & $>294$ & $<0.02$ & $\begin{array}{c}0.36 \pm 0.09 \\
0.22-0.42\end{array}$ & $\begin{array}{c}1.15 \pm 0.89 \\
0.28-2.87\end{array}$ & $\begin{array}{c}2.03 \pm 1.18 \\
0.4-3.6\end{array}$ & $<0.04$ \\
\hline
\end{tabular}

$* P=0.05 ; *+P<0.025 ; *+P<0.0025$; ranked sum test (comparison of $\mathrm{R}$ ws NR). 


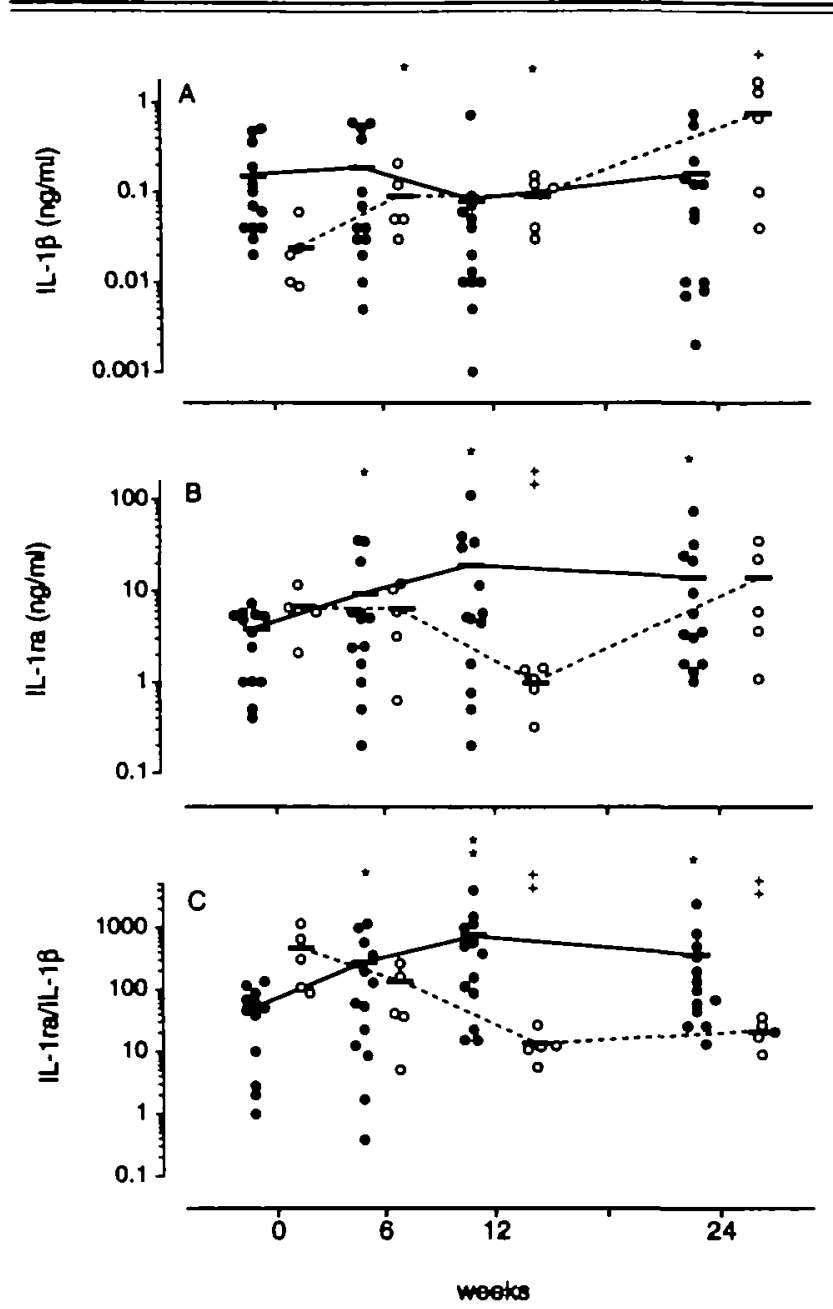

FIG. 2.-Spontaneous interleukin-1 $\beta$ (IL-1 $\beta$ ) and interleukin-1 receptor antagonist (IL-Ira) production of PBMC and their ratio during 24 weeks of MTX treatment. Peripheral blood mononuclear cells $\left(2 \times 10^{5}\right)$ of rheumatoid arthritis patients $(n=18)$ were obtained before, and after 6,12 and 24 weeks of methotrexate treatment and cultured in quadruplicates for 2 days in medium containing $1 \%$ plasma protein solution. IL-1 $\beta$ (A) and IL-Ira (B) production of responding $(O ; n=13)$ and non-responding $(O ; n=5)$ patients was determined in cell culture supernatants. Ratios of individual ILIra:IL-1 $\beta$ production were calculated (C). Values of individual patients and their corresponding means are shown. ${ }^{*} P<0.05$, ${ }^{+} P<0.02,{ }^{* *} P<0.025,{ }^{++} P<0.01$ (refers to intragroup comparisons).

their non-responding counterparts $(P<0.0025)$. In contrast, pretreatment levels of constitutive IL-8, MCP-1, sTNFR p55 and $\mathrm{p} 75$ production did not differ significantly between the two patient groups and except for one non-responding patient TNF- $\alpha$ was not detectable. In contrast to RA patients, very small amounts of spontaneous IL- $1 \beta$ production by PBMC were detected only in $50 \%$ of healthy individuals.

Spontaneous cytokine and cytokine inhibitor production of PBMC during MTX treatment

Figures 2-4 show the differences between patients with and without clinical improvement after 6,12 and 24 weeks of treatment. There was no significant change
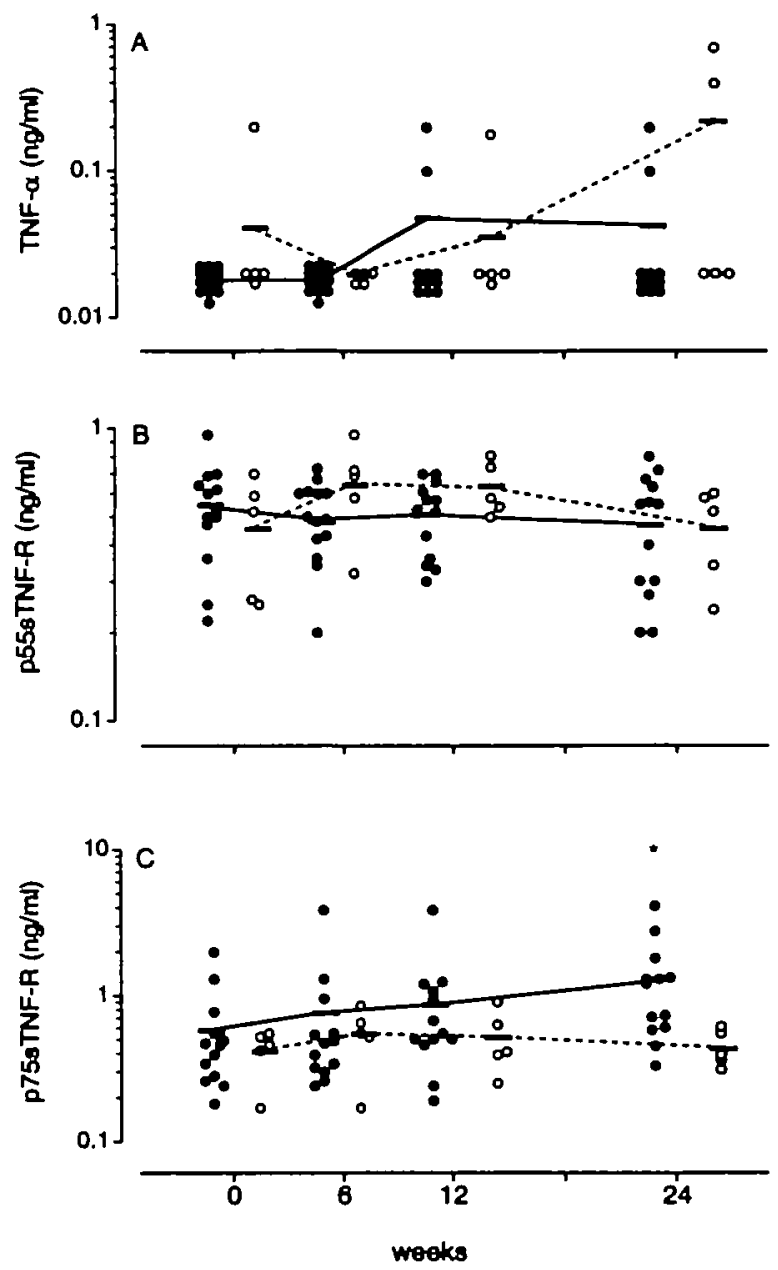

Fig. 3.-Spontaneous tumour necrosis factor alpha (TNF- $\alpha$ ), soluble tumour necrosis factor receptors (sTNFR) p55 and p75 production of peripheral blood mononuclear cells (PBMC) during 24 weeks of methotrexate (MTX) treatment. PBMC $\left(2 \times 10^{5}\right)$ of rheumatoid arthritis patients $(n=18)$ were obtained before, and after 6,12 and 24 weeks of MTX treatment and cultured in quadruplicates for 2 days in medium containing $1 \%$ plasma protein solution. TNF- $\alpha$ (A), sTNFR p5S (B), and sTNFR p75 (C) production of responding $(\Theta ; n=13)$ and non-responding $(O ; n=5)$ patients was determined in cell culture supernatants. Values of individual patients and their corresponding means are shown. $* P<0.05$ (refers to intragroup comparisons).

of constitutive IL- $1 \beta$ release from PBMC of 'responders', whereas cells from 'non-responders' exhibited enhanced IL- $1 \beta$ production during treatment $(P<0.05$ after $6, P<0.05$ after 12 and $P<0.02$ after 24 weeks) (Fig. 2A). In contrast, we found elevated levels of IL-1 ra in responding patients after $6(P<0.05), 12$ $(P<0.05)$ and 24 weeks $(P<0.05)$ but markedly decreased levels (week 12,P<0.01) in non-responding patients (Fig. 2B). Calculation of the IL-1 ra:IL-1 $\beta$ ratio for each RA patient allowed us to get information about changes of the inflammatory type of blood mononuclear cells during MTX treatment. The mean ratio of the responder group increased concomitantly with clinical improvement after $6(P<0.05), 12$ $(P<0.025)$ and $24(P<0.05)$ weeks of treatment. In 


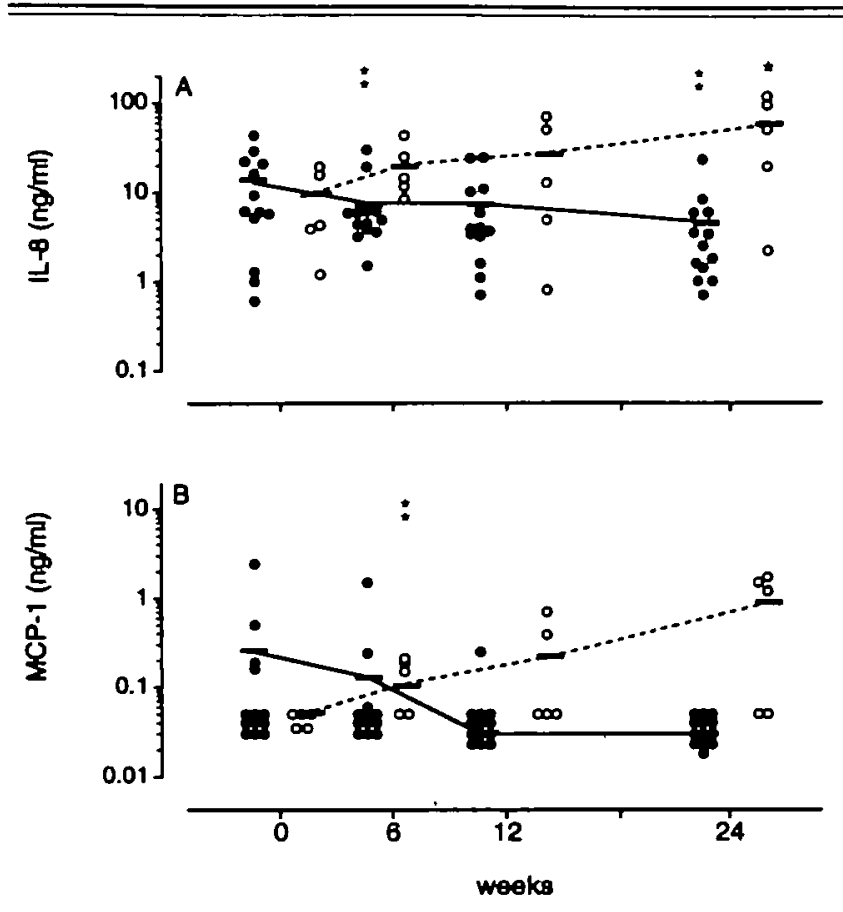

Fю. 4. - Spontaneous interleukin-8 (IL-8) and monocyte chemoattractant protein-1 (MCP-1) production of peripheral blood mononuclear cells (PBMC) during 24 weeks of methotrexate (MTX) treatment. PBMC $\left(2 \times 10^{5}\right)$ of rheumatoid arthritis patients $(n=16)$ were obtained before, and after 6, 12 and 24 weks of MTX treatment and cultured in quadruplicates for 2 days in medium containing $1 \%$ plasma protein solution. IL-8 (A) and MCP-1 (B) production of responding $(O ; n=13)$ and non-responding $(\mathrm{O}$; $n=5$ ) patients was determined in cell culture supernatants. Values of individual patients and their corresponding means are shown. $* P<0.05, * P<0.025$ (refers to intragroup comparisons).

contrast, the higher baseline ratio of non-responders before treatment declined over 12 weeks $(P<0.01)$ and remained at a low level $(P<0.01)$ after 24 weeks (Fig. 2C). Levels of TNF- $\alpha$ and sTNFR p55 did not vary significantly during MTX treatment, whereas sTNFR p75 was slightly upregulated in clinical responders $(P<0.05$ at week 24$)$ (Fig. 3A-C). PBMC of RA patients produced considerable amounts of IL-8 and in a few cases low amounts of MCP-1. IL-8 release from PBMC of clinical responders was downregulated after $6(P<0.025)$ and 24 weeks $(P<0.025)$, whereas in non-responders IL-8 was upregulated $(P<0.05)$ (Fig. 4A, B).

\section{In vitro stimulated cytokine production of $P B M C$ obtained during MTX treatment}

Upon in vitro stimulation with IL-1 $\alpha$, production of IL- $\beta \beta$ and IL-8 by PBMC of responding patients declined after 12 or 24 weeks of in vivo MTX treatment $(P<0.05 ; P<0.025$; Fig. 5A, B), whereas synthesis of TNF- $\alpha$, soluble TNF- $\alpha$ receptors, IL- 1 ra and of MCP-1 were not affected (data not shown). A similar downregulation of IL-8 but also of TNF- $\alpha$ was observed after in vitro stimulation of PBMC with $1 \mathrm{~L}-1 \beta$ $(P<0.025$ and $P<0.05$ after 24 weeks) (Fig. 6A, B). In contrast, cells from non-responders exhibited an enhanced production of TNF- $\alpha$ after 24 weeks

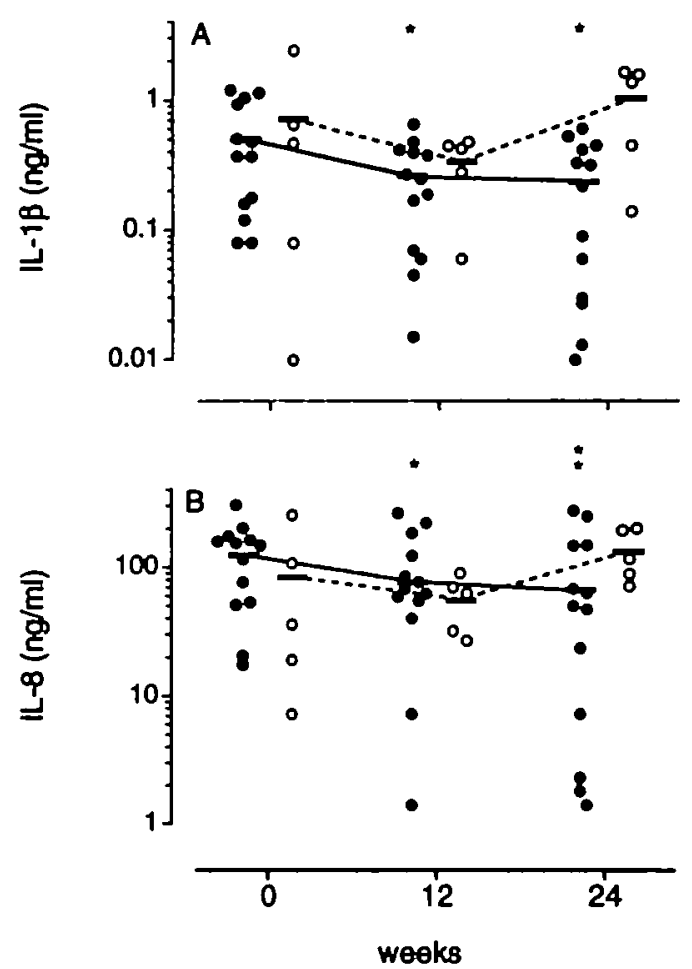

Fio. 5.-In vitro interleukin-l $\alpha$ (IL-l $\alpha$ )-stimulated cytokine production of peripheral blood mononuclear ceils (PBMC) during 24 weeks of methotrexate treatment. PBMC $\left(2 \times 10^{5}\right)$ of rheumatoid arthritis patients $(n=18)$ were obtained before, after 6,12 and 24 weeks of MTX treatment and cultured in quadruplicates for 2 days in medium containing $\mathrm{IL}-1 \alpha(10 \mathrm{ng} / \mathrm{ml})$ and $1 \%$ plasma protein solution. IL-1 $\beta$ (A) and IL-8 (B) production of responding $(O ; n=13)$ and non-responding $(O ; n=5)$ patients was determined in cell culture supernatants. Values of individual patients and their corresponding means are shown. ${ }^{*} P<0.05,{ }^{* *} P<0.025$ (refers to intragroup comparisons).

$(P<0.01 ;$ Fig. 6A). After stimulation with LPS PBMC of 'responders' showed a significant decline of IL-8 production after 24 weeks of MTX treatment (Fig. 7A; $P<0.01$ ), whereas IL-8 release in non-responders remained unaffected. The release of IL-1 ra, sTNFR and MCP-I was not modulated under these conditions (data not shown). Cytokine levels after 6 weeks of treatment are not shown, because they did not differ from baseline values.

\section{DISCUSSION}

First, our study shows that conventional clinical and laboratory criteria alone are insufficient to discern whether a patient will respond or not respond to low-dose MTX treatment. We found that a favourable therapeutic response of our patients was associated in $84.6 \%$ with a pretreatment ratio of constitutive ILIra:IL-1 $\beta$ production by PBMC of lower than 100 , whereas a pretreatment ratio of higher than 100 was observed in $80 \%$ of the non-responding patients. Based on this finding, we assume that a high inflammatory activity of monocytes as reflected by high IL-1 $\beta$ and relatively low IL-1 ra production may give a hint to a more favourable response to MTX treatment in the 

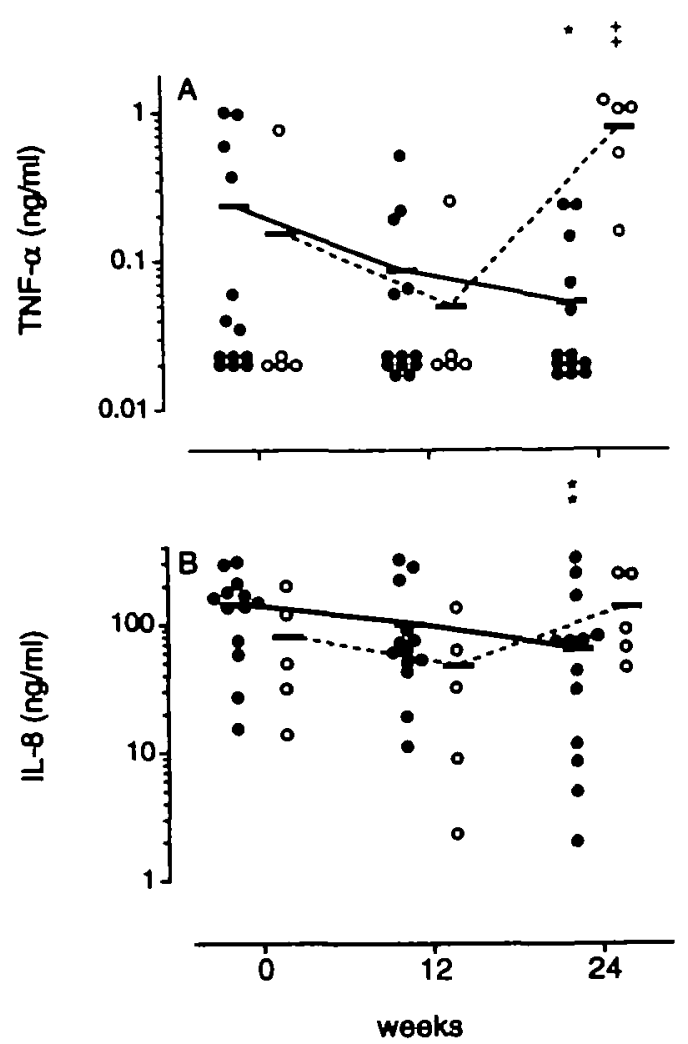

FiG. 6. - In vitro interleukin- $1 \beta$ (IL-1 $\beta$ )-stimulated cytokine production of peripheral blood mononuctear cells (PBMC) during 24 weeks of methotrexate (MTX) treatment. PBMC $\left(2 \times 10^{5}\right)$ of rheumatoid arthritis patients $(n=18)$ were obtained before, and after 6,12 and 24 of MTX treatment and cultured in quadruplicates for 2 days in medium containing IL- $1 \beta(10 \mathrm{ng} / \mathrm{ml})$ and $1 \%$ plasma protein solution. Tumour necrosis factor $\alpha$ (A) and interleukin-8 (B) production of responding $(O ; n=13)$ and non-responding $(O$; $n=5)$ patients was determined in cell culture supernatants. Values of individual patients and their corresponding means are shown. * $P<0.05,{ }^{* *} P<0.025,{ }^{++} P<0.01$ (refers to intragroup comparisons).

majority of RA patients. In contrast, pretreatment levels of TNF- $\alpha$, sTNFR, IL-8 and MCP-1 production of PBMC were found to be irrelevant for prediction of treatment outcome. This is the first study that suggests IL-Ira and IL-1 $\beta$ production by blood monocytes as a possibly useful prognostic marker for the therapeutic response of RA patients to MTX.

The second finding in our study is that clinical improvement is accompanied by stimulation of spontaneous IL-1ra and STNFR p75 production by PBMC. A significant increase of IL-1 ra in most patients together with unchanged or decreased IL- $1 \beta$ release from PBMC resulted in a 4-14-fold increase of the IL1 ra: IL-1 $\beta$ ratio after 6-24 weeks of MTX treatment in clinically improved patients. In clinical nonresponders this ratio markedly declined during treatment. Though all responding patients showed most impressive clinical improvement 12 weeks after starting MTX treatment, disease activity significantly declined already after 6 weeks. Accordingly, the 6-week values at least of IL-1 ra and IL-8 showed a small but significant differ-

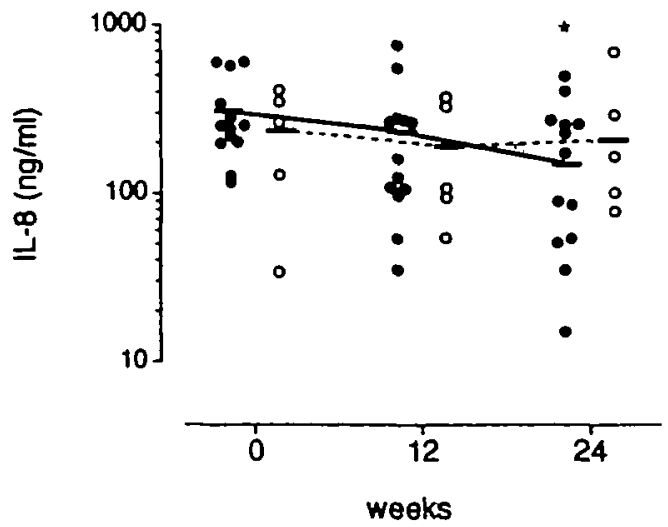

Fig. 7.-In vitro bacterial lipopolysaccharide (LPS)-stimulated interleukin-8 (IL-8) production of peripheral blood mononuclear cells (PBMC) during 24 weeks of methotrexate (MTX) treatment. PBMC $\left(2 \times 10^{5}\right)$ of rheumstoid arthritis patients $(n=18)$ were obtained before, and after 6,12 and 24 weeks of MTX treatment and cultured in quadruplicates for 2 days in medium containing LPS $(100 \mathrm{ng} / \mathrm{ml})$ and $1 \%$ plasma protein solution. IL-8 production of responding (O; $n=13)$ and non-responding $(O ; n=5)$ patients was determined in cell culture supernatants. Values of individual patients and their corresponding means are shown. $P<0.01$ (refers to intragroup comparisons).

ence from baseline. The anti-inflammatory effect observed clinically fits well with the 100 -fold excess of IL-1 ra which is needed in vitro and in vivo to effectively antagonize IL-1-mediated activation of T-cells, fibroblasts and chondrocytes $[17,30]$. An excess of IL-1ra production most likely occurs in active RA, as evidenced by the very high levels of this protein found in the synovial fluids of RA patients compared to very low amounts of IL-1 $\beta$ [25]. Why is there nevertheless on-going synovitis in this patients? This question is still unsolved.

It is conceivable that IL-1 ra production in rheumatoid synovial tissue may not be in sufficient excess to inhibit the proinflammatory effects of locally produced IL-1. From the therapeutic view, therefore, an even higher excess of IL-1ra over IL-1 production seems warranted. This could be achieved either by IL-l ra stimulation as shown in this study or by diminishing IL-1 production as found recently in synovial fluid of RA patients undergoing MTX treatment [31]. Another explanation for insufficient anti-inflammatory action of endogenously produced IL-1 ra in rheumatoid synovitis may be that other cytokines such as TNF- $\alpha$ may be more important in the initiation and perpetuation of the disease process [32]. In this study we also found a late upregulation of STNFR p75 synthesis of PBMC after 24 weeks of treatment which was associated with clinical improvement. This may indicate that for longterm anti-inflammatory regulation of the cytokine network by MTX, beside IL-1 ra stimulation, enhanced STNFR synthesis may be also important. We further presume that downregulation of constitutive chemokine release from PBMC of clinical responders is most likely the consequence of an increased inhibition of IL-1-mediated monocyte activation due to enhanced 
IL-1ra. The downregulation of IL-8 in the course of MTX treatment and its coincidence with enhanced cytokine inhibitor production supports this assumption.

The upregulation of sTNFR p75 without affecting sTNFR p55 contrasts with a previous study [33] showing reduced sTNFR p55 levels in sera of RA patients responding to MTX treatment. Because cytokine levels measured in serum represent the net result of production and clearance within the circulation without giving information about the source of production, we believe that examination of cytokine regulation on the cellular level as surveyed in this study will give better insight into the effects of any therapeutic intervention on the unbalanced cytokine network in RA. Because STNFR in serum behave like acute phase proteins as shown by elevated levels according to inflammatory disease activity in RA and systemic lupus erythematosus $[33,34]$ as well as after surgery [35], we think that changes of serum STNFR levels might merely reflect epiphenomena.

Furthermore, our study shows that in clinical responders MTX treatment in vivo reduced IL-1 and LPS-induced cytokine release from PBMC in vitro. This was documented by the marked downregulation of PBMC capacity to synthesize IL-1 $\beta$, TNF- $\alpha$ and IL-8 after corresponding stimulation. In contrast to sTNFR p75, sTNFR p55 production of PBMC was not regulated by either systemic MTX treatment in vivo or cytokine or LPS mediated stimulation in vitro. The expression and shedding of both sTNFR may be indeed distinctly regulated $[27,36]$. Interestingly, in a recent study, pretreatment with ibuprofen in human experimental endotoxinaemia increased and prolonged concentrations of TNF- $\alpha$ and sTNFR p75 in the circulation without affecting p55 levels [37]. It is therefore possible that concomitant NSAID therapy in all our patients may be responsible for the finding of a distinct regulation of p55 and p75 sTNFR.

In conclusion, these results indicate that MTX treatment clearly affects cytokine inhibitor and cytokine production of PBMC which may explain its rapid and long-lasting anti-inflammatory effects when administered continuously to RA patients. However, changes of cytokine profiles observed in this study may occur as the final common pathway of all therapies and are not necessarily specific for MTX. Although not measuring whole IL-1 $(\alpha+\beta)$, our results give a hint that beside clinical parameters a low ratio of IL-I ra:IL-1 $\beta$ production of PBMC might be an additional help to predict favourable clinical response to MTX treatment. Further studies with larger numbers of patients are needed to decide definitely whether pretreatment screening for IL-1ra and IL-1 $\beta$ production of PBMC should be generally recommended before starting therapy with MTX or other second-line drugs in RA.

\section{ACKNOWLEDGEMENTS}

This study was supported by the Swiss National Science Foundation grant 32-40408.94 and by a subvention of the 'Swiss Federal Commission Against
Rheumatic Diseases' to MS. We thank M. Zwicker and A. Blaser for excellent technical assistance and D. Messer for secretarial work.

\section{REFERENCES}

1. Weinblatt ME, Coblyn JS, Fox DA, Fraser PA, Holdsworth DE, Glass DN, Trentham DE. Efficacy of low dose methotrexate in rheumatoid arthritis. $N$ Engl $J$ Med 1985;312:818-22.

2. Williams HJ, Wilkens RF, Samuelson CO Jr, Alarcón GS, Guttadauria M, Yarboro C, Polisson RP, Weiner SR, Luggen ME, Billingsley LM, Dahl SL, Egger MJ, Reading JC, Ward JR. Comparison of low-dose oral pulse methotrexate and placebo in the treatment of rheumatoid arthritis. A controlled clinical trial. Arthritis Rheum 1985;28:721-30.

3. Kremer JM, Phelps CT. Long-term prospective study of the use of methotrexate in rheumatoid arthritis: update after a mean of 90 months. Arthritis Rheum 1992; 35:138-45.

4. Weinblatt ME, Weissman BN, Holdsworth DE et al. Long-term prospective study of methotrexate in the treatment of rheumatoid arthritis: eighty-four month update. Arthritis Rheum 1992;35:129-37.

5. Felson DT, Anderson JJ, Meenan RF. Use of short-term efficacy/toxicity tradeoffs to select second-line drugs in rheumatoid arthritis. A metaanalysis of published clinical trials. Arthritis Rheum 1992;35:1117-25.

6. Segal R, Yaron M, Tartakovsky B. Methotrexate: mechanism of action in rheumatoid arthritis. Semin Arthritis Rheum 1990;20:190-9.

7. Kremer JM, Rynes RI, Bartholomew BL. Severe flare of rheumatoid arthritis after discontinuation of long-term methotrexate therapy. Double-blind study. Am J Med 1987;82:781-6.

8. Segal R, Mozes E, Yaron M, Tartakovsky B. The effects of methotrexate on the production and activity of interteukin-1. Arthritis Rheum 1989;32:370-7.

9. Chang DM, Weinblatt ME, Schur PH. The effects of methotrexate on interleukin-1 in patients with rheumatoid arthritis. $J$ Rheumatol 1992;19:1678-82.

10. Brody M, Bohm I, Bauer R. Mechanism of action of methotrexate: experimental evidence that methotrexate blocks the binding of interleukin- $1 \beta$ to the interleukin-1receptor on target cells. Eur $J$ Clin Chem Clin Biochem 1993;31:667-74.

11. Hu SK, Mitcho YL, Oronsky AL, Kerwar SS. Studies on the effect of methotrexate on macrophage function. $J$ Rheumatol 1988;15:206-9.

12. Johnson WJ, Di Martino MJ, Meunier PC, Muirhead KA, Hanna N. Methotrexate inhibits macrophage activation as well as vascular and cellular inflammatory events in rat adjuvant induced arthritis. $J$ Rheumatol 1988;15:745-9.

13. Seitz M, Dewald B, Ceska M, Gerber N, Baggiolini $M$. Interleukin-8 in inflammatory rheumatic diseases: synovial fluid levels, relation to rheumatoid factors, production by mononuclear cells, and effects of gold sodium thiomalate and methotrexate. Rheumatol Int 1992;12:159-64.

14. Sperting RI, Benincaso AI, Anderson RJ, Coblyn JS, Austen KF, Weinblatt ME. Acute and chronic suppression of leukotriene $B_{4}$ synthesis ex vivo in neutrophils from patients with rheumatoid arthritis beginning treatment with methotrexate. Arthritis Rheum 1992;35: $376-84$ 
15. Firestein GS, Paino MM, Boyle DL. Mechanisms of methotrexate action in rheumatoid arthritis. Arthritis Rhewn 1994;37:193-200.

16. Cronstein BN, Eberle MA, Gruber HE, Levin RI. Methotrexate inhibits neutrophil function by stimulating adenosine release from connective tissue cells. Proc Natl Acad Sci USA 1991;88:2441-5.

17. Dayer JM, Fenner $H$. The role of cytokines and their inhibitors in arthritis. Baillière's Clin Rheumatol 1992;6:485-516.

18. Roux-Lombard P, Modoux C, Vischer T, Grassi J, Dayer JM. Inhibitors of interleukin-1 activity in synovial fluids and in cultured synovial fluid mononuclear cells. $J$ Rheumatol 1992;19:517-23.

19. Firestein GS, Berger AE, Tracey DE et al. IL-1 receptor antagonist protein production and gene expression in rheumatoid arthritis and osteoarthritis synovium. $J$ Immunol 1992;149:1054-62.

20. Roux-Lombard P, Punzi L, Hasler F, Bas S, Todesco S, Gallati H, Guerne PA, Dayer JM. Soluble tumor necrosis factor receptor in human inflammatory synovial fluids. Arthritis Rheum 1993;36:485-9.

21. Paulus HE, Egger MJ, Word JR, Williams HJ. Analysis of improvement in individual rheumatoid arthritis patients treated with disease-modifying antirheumatic drugs, based on the findings in patients treated with placebo. Arthritis Rheum 1990;33:477-84.

22. Boyum A. Isolation of lymphocytes, granulocytes and macrophages. Scand J Immunol 1976;5:9-15.

23. Koski JR, Poplek DG, Blaese RMA. Nonspecific esterase stain for the identification of monocytes and macrophages. In: Bloom CNR, David JR, eds. In vitro methods in cells mediated and tumor immunity. New York: Academic Press, 1976:359.

24. Hãupl T, Burmester GR, Hahn G, Feige U, RordorfAdam C, Kalden JR. Differential immunological response of patients with rheumatoid arthritis towards two different Epstein-Barr virus strains: inhibition of interleukin-1 release by the B 95-8, but not the P3HR-1 virus strain. Rheumatol Int 1989;9:153-60.

25. Towbin HA, Schmitz A, von Oostrum J, Seitz M, Dewald B, Zingel O, Motz J, Rordorf C. A monoclonal antibody-based ELISA for the human interleukin-1 receptor antagonist: its application to measure hIL-1 ra levels in monocytes cultures and in synovial fluids. I Immunol Methods 1994;170:125-35.

26. Elsässer-Beile U, von Kleist $S$, Stähle W, SchurhammerFurhmann C, Schulte-Mönting J, Gallati H. Cytokine levels in whole blood cell cultures as parameters of the cellular immunologic activity in patients with malignant melanoma and basal carcinoma. Cancer 1993;71:231-6.
27. Heilig B, Wermann M, Gallati H, Brockhaus $M$, Berke B, Egen O, Pezzutto A, Hunstein W. Elevated TNF receptor plasma concentrations in patients with rheumatoid arthritis. Clin Invest 1992;70:22-8.

28. Bazzoni F, Cassatella MA, Rossi F, Ceska M, Dewald B, Baggiolini $M$. Phagocytosing neutrophils produce and release high amounts of the neutrophil-activating peptide 1/interleukin-8. J Exp Med 1991;173:771-4.

29. Lötscher P, Dewald B, Baggiolini M, Seitz M. Monocyte chemoattractant protein-1 and interleukin-8 production by rheumatoid synoviocytes. Effects of antirheumatic drugs. Cytokine 1994;6:162-70.

30. Arend WP. Interleukin-1 receptor antagonist. Adv Immunol 1993;54:167-227.

31. Thomas R, Carroll GJ. Reduction of leucocyte and interleukin- $1 \beta$ concentrations in the synovial fluid of rheumatoid arthritis patients treated with methotrexate. Arthritis Rheum 1993;36:1244-52.

32. Brennan FM, Maini RN, Feldmann M. TNF- a a pivotal role in rheumatoid arthritis? $\mathrm{Br} J$ Rheumatol 1992; 31:293-8.

33. Barrera $P$, Boerbooms AMT, Janssen EM, Sanerwein RW, Gallati H, Mulder J, de Veo T, Demacker PNM, van de Putte LBA, von der Meer JWM. Circulating soluble tumor necrosis factor receptors, interleukin-2 receptors, tumor necrosis factor $\alpha$, and interleukin-6 levels in rheumatoid arthritis. Longitudinal evaluation during methotrexate and azathioprine therapy. Arthritis Rheum 1993;36:1070-9.

34. Aderka D, Wysenbeek A, Engelmann H, Cope AP, Brennan F, Molad Y, Hornik V, Levo Y, Maini RN, Feldmann M, Wallach D. Correlation between serum levels of soluble tumor necrosis factor receptor and disease activity in systemic lupus erythematosus. Arthritis Rheum 1993;36:1111-20.

35. Chikawza IC, Roux-Lombard P, Dayer JM, Panayi GS. Tumor necrosis factor soluble receptors behave as acute phase reactants following surgery in patients with rheumatoid arthritis, chronic osteomyelitis and osteoarthritis. Clin Exp Immunol 1993;92:19-22.

36. Deleuran BW, Chu CG, Field M, Brennan FM, Mitchell T, Feldmann M, Maini RN. Localization of tumor necrosis factor receptors in the synovial tissue and cartilage-pannus junction in patients with rheumatoid arthritis: implications for local actions of tumor necrosis factor $\alpha$. Arthritis Rhewm 1992;35:1170-8.

37. Spinas GA, Keller U, Brockhaus M. Release of soluble receptors for tumor necrosis factor (TNF) in relation to circulating TNF during experimental endotoxinemia. $J$ Clin Invest 1992;90:533-6. 